Communication

\title{
Chemical Composition of Essential Oil of Leaves from Lippia schaueriana Mart. Collected in the Caatinga Area
}

\author{
Ana Valéria Vieira de Souza ${ }^{1, *}$, Uiliane Soares dos Santos ${ }^{2}$, Jackson Rafael de Sá Carvalho ${ }^{2}$, \\ Bruno Djvan Ramos Barbosa ${ }^{2}$, Kirley Marques Canuto ${ }^{3}$ and Tigressa Helena Soares Rodrigues 4 \\ 1 Embrapa Semiarid, 56302-970 Petrolina-PE, Brazil \\ 2 State University of Feira de Santana (UEFS), 44036900 Feira de Santana, Bahia, Brazil; \\ uilianesoares@hotmail.com (U.S.d.S); rafael_.carvalho@hotmail.com (J.R.d.S.C.); \\ brunodj31@hotmail.com (B.D.R.B.) \\ 3 Embrapa Tropical Agroindustry, 60511-110 Fortaleza-CE, Brazil; kirley.canuto@embrapa.br \\ 4 State Universityof Vale do Acaraú (UVA), 62040-370 Sobral-CE, Brazil; thelenasr@yahoo.com.br \\ * Correspondence: ana.souza@embrapa.br; Tel.: +55-87-3866-3808
}

Received: 23 May 2018; Accepted: 6 July 2018; Published: 27 September 2018

\begin{abstract}
Lippia schaueriana Mart. (Verbenaceae) is an endemic species of Caatinga with a restricted distribution to the states of Bahia and Pernambuco, which presents itself as a potential source of raw material for extraction of essential oil and exploitation by the chemical and pharmaceutical industries. Considering that there are no reports in the literature of research carried out with this species, this paper aimed to establish-for the first time-the chemical composition of its essential oil. The essential oil of the dry leaves at room temperature was obtained by hydrodistillation after $3 \mathrm{~h}$ of extraction and the phytochemical analyzes were done by gas chromatography coupled to mass spectrometry (GC/MS). The main compounds found in the oil of leaves were piperitone oxide $(51.25 \%)$, caryophyllene $(17.76 \%)$, limonene $(8.06 \%)$, spathulenol $(6.63 \%)$, and piperitone (2.90\%). The piperitone oxide is a compound described in the literature that shows antinociceptive, cardiovascular, analgesic, and relaxing activities, as well as fungicidal and insecticidal effect, which gives it an interesting potential for the alternative control of agricultural pests.
\end{abstract}

Keywords: endemic; medicinal plant; lipia da serra; piperitone; limonene

\section{Introduction}

The genus Lippia (Verbenaceae) includes approximately 200 species of herbs, shrubs, and small trees, most of which are distributed in the Neotropical region [1]. Brazil is the center of diversity of the genus, containing 98 species with a high degree of endemism, more than half of which is located in the Serra do Espinhaço in the state of Minas Gerais [2].

Lippia shaueriana Mart. is a Caatinga endemic species, whose distribution is restricted to the states of Bahia and Pernambuco. It was described for the first time growing in pastures in Pernambucano state, between Bom Jardim and Cruz de Valerio cities [3]. The plant has a bush structure, with thick and tetragonal branches. It presents oval, rough, opposing leaves with irregular borders $[4,5]$. In the region, it is popularly known as "lipia da serra", "alecrim da serra", and "alecrim de mocó". The popular denomination "lipia da serra" refers to the place where the species occurs, which can be observed in small hills with altitudes above $400 \mathrm{~m}$. The popular names "alecrim da serra" and "alecrim de mocó" make reference to the bushy rosemary or wild rosemary, as is known the Lippia gracilis species. The name mocó comes from the small rodent Kerodon rupestris (Caviidae) that occurs in the same region [6]. 
Although there are no reports in the literature of scientific research conducted with this species to prove any therapeutic effect, its leaves contain essential oils and are used in rural communities in both Pernambuco and Bahia states for inhalations and baths to treat cold, flu, and headaches.

The essential oils are defined by the International Standards Organization (ISO) as the products obtained from parts of plants by steam distillation as well as products obtained by crushing citrus fruit pericarp. They are complex mixtures of volatile substances, lipophilic, liquid, colorless or slightly yellowish, which have as basic characteristic the smell and the flavor. Their constituents vary from terpene hydrocarbons, aldehydes, ketones, phenols, lactones, coumarins, organic acids among others and, in the mixture, there is a variation in the concentration of these compounds, one of them being the majority compound. They are localized in specialized secretory structures, such as glandular, differentiated parenchyma cells, oil channels or even lysigenic or schizoligene bags, and may occur in only one plant organ or in the whole plant $[7,8]$.

The essential oils concentration in the different parts of the plants varies qualitatively and quantitatively in relation to several factors, mainly the soil, the climate, the period of the day and the seasons of the year and the types and doses of fertilization [9]. Essential oils obtained in different organs of the same plant can have significantly different chemical composition, odor and physicochemical characteristics [10,11].

Essential oils have extremely important biological functions in the plant kingdom, such as the attraction of pollinating agents and the protection against certain plant pathogens. Due to the pleasant aroma and chemical constitution, which confers significant therapeutic properties, this important metabolite has been a constant target of the chemical, pharmaceutical, and fragrance industries.

The results presented in this study have not been published before and were obtained through the research carried out at Embrapa semi-arid located in Petrolina-PE, Brazil. These results revealed the strong potential of the Lippia schaueriana Mart. species as a source of raw material to obtain essential oil that can be used commercially by chemical, pharmaceutical, and fragrance industries. Considering the high potential of this plant species for commercial exploration, as well as the lack of published data, this study aimed, for the first time, to characterize the chemical composition of the essential oil extracted from L. schaueriana leaves.

\section{Results}

The results of the essential oil analysis of L. schaueriana are presented in Table 1, according to their retention indexes. The chromatogram of oil exhibited 21 peaks, which led to the identification of 19 components, representing $97.99 \%$ of the total oil composition. The main compounds found in the oil of leaves were piperitone oxide $(51.25 \%)$, caryophyllene $(17.76 \%)$, limonene $(8.06 \%)$, spathulenol $(6.63 \%)$, and piperitone $(2.90 \%)$ (Table 1$)$.

Table 1. Chemical composition of essential oil of dried leaves of Lippia schaueriana (Verbenaceae).

\begin{tabular}{cccccc}
\hline Peak & RT $(\mathbf{m i n})$ & RI $^{*}$ & RI literature & Compound & \% GC-MS \\
\hline 1 & 5.79 & 1025 & 1024 & p-Cymene & 0.23 \\
2 & 5.91 & 1030 & 1029 & Limonene & 8.06 \\
3 & 6.23 & 1058 & 1059 & cis- $\beta$ Ocimene & 0.54 \\
4 & 7.78 & 1100 & 1096 & Linalool & 0.30 \\
5 & 8.60 & 1121 & 1122 & Mentha-2.8-dien-1-ol (trans) & 1.05 \\
6 & 9.06 & 1135 & 1137 & Mentha-2.8-dien-1-ol (cis) & 0.23 \\
7 & 11.72 & 1148 & 1149 & Myrcenone & 2.04 \\
8 & 11.78 & 1208 & 1229 & Trans-carveol & 0.53 \\
9 & 12.66 & 1236 & 1243 & Carvone & 0.55 \\
10 & 14.13 & 1291 & 1290 & Thymol & 1.10 \\
11 & 14.28 & 1299 & 1299 & Carvacrol & 0.40 \\
12 & 15.52 & 1338 & 1342 & Trans-carvenyl-acetate & 1.22 \\
13 & 15.83 & 1342 & 1343 & Piperitone & 2.90 \\
14 & 16.56 & 1370 & 1368 & Piperitone oxide & 51.25 \\
\hline
\end{tabular}


Table 1. Cont.

\begin{tabular}{cccccc}
\hline Peak & RT (min) & RI $^{*}$ & RI literature & Compound & \% GC-MS \\
\hline 15 & 17.72 & 1422 & 1419 & $\beta$-Caryophyllene & 17.76 \\
16 & 20.81 & 1498 & 1500 & Bicyclogermacrene & 1.59 \\
17 & 21.05 & 1509 & 1505 & B-Bysabolene & 0.44 \\
18 & 23.26 & 1580 & 1578 & Spathulenol & 6.63 \\
19 & 24.86 & 1585 & 1583 & Caryophyllene oxide & 1.77 \\
20 & 30.15 & 1865 & - & NI & 1.14 \\
21 & 33.63 & 2127 & - & NI & 0.29 \\
Total & & & & & $\mathbf{9 7 . 9 9 \%}$ \\
\hline
\end{tabular}

RT: retention time. ${ }^{*}$ RI: retention indices on DB-5MS column (relative to $n$-alkanes). ${ }^{* *}$ Adams (1995). (一): Not determined. NI: not identified compound.

\section{Discussion}

Piperitone oxide or piperitone are monoterpenes that have been described as major components of the essential oils of species of the genus Hyptis spp., Mentha spp. and Clinopodium odorum [12-14]. This first monoterpene is a clear, slightly yellowish liquid, chemically termed 3-isopropyl-6-methyl-7-oxa-bicyclo [4.1.0] heptan-2-one of molecular formula $\mathrm{C}_{10} \mathrm{H}_{14} \mathrm{O}_{2}$ and molecular weight 166.21. It is soluble in water and organic solvent. Piperitone is derived from the metabolic pathway for the formation of piperitenone oxide, in which cis-pulegone is also derived $[15,16]$ reported that this terpene has three organic functions in its chemical structure and can be used for the synthesis of other compounds.

The essential oil of Mentha villosa presents as major compounds rotundifolone and piperitone oxide [16,17]. The latter compound was attributed to analgesic and relaxing activities [18,19], insecticide [16], and antinociceptive [20], beyond the control of protozoan intestinal parasites [21].

In a study of Mentha rotundifolia, the concentration of piperitone oxide in the essential oil reached 80\% [15] and was used to define Mentha pulegium chemotypes [10]. Among several peppermint chemotypes, some also present piperitone oxide as the major compound of essential oil [22,23]. These latter authors attribute that this compound is potentially responsible for cardiovascular effects, antibacterial and antifungal agents, repellents, and retarders of malaria vector reproduction (Anopheles stephensi).

Concentrations between 0.1 and $10 \mathrm{ug} \cdot \mathrm{mL}^{-1}$ of piperitenone oxide present in some species of Mentha, presented a potentiating effect of the contraction induced by acetylcholine (ACh) and doses greater than $30 \mathrm{ug} \cdot \mathrm{mL}^{-1}$, were revealedas depressor intestinal smooth muscle in the contractions caused by $\mathrm{KCl}, \mathrm{Ach}$, and tetraethylammonium [19].

In addition to the effect on the control of protozoan intestinal parasites, it is also attributed to the relevant piperitenone oxide antimicrobial activity, fungicide, and insecticide, which gives it an interesting potential for alternative pest control $[11,15,21]$.

The chemical composition and relevant antimicrobial activities of other species of the genus Lippia spp. have been well investigated and some studies have already shown antifungal and antibacterial activity against several microorganisms of agricultural, medical, and veterinary importance [24-29]. However, the compounds reported as effective in this context by the various authors are carvacrol and thymol, the latter being also present in the essential oil of L. schaueriana (Table 1). The variation between the chemical composition of the essential oil of $L$. schaueriana and other species of the genus are related to the factors that influence the content of the secondary metabolites in plants, as presented previously [9].

Although this species presents itself as a potential source of raw material for the exploration of industries interested in obtaining products from the Brazilian flora, be it drugs or products with biopesticidal action, there are no records in the literature of any research done with the same, mainly in the field of natural product chemistry.

In this context and considering the endemism of the species with relevant potential of use, the elucidation of the chemical composition of its essential oil represents a significant contribution 
to the scientific community, since this research can serve as a subsidy for several areas of inter and multidisciplinary science. From these results, chemical, agronomic and pharmaceutical studies can be carried out, in which the sustainable management of the species and of this important Caatinga ecosystem should be sought.

\section{Materials and Methods}

Fresh leaves of Lippia schaueriana Mart. were collected in august of 2014 in Petrolina (Coordinates: $9^{\circ} 4^{\prime} 4.19^{\prime \prime}$ S; $40^{\circ} 19^{\prime} 42.24^{\prime \prime}$ W), State of Pernambuco, Brazil. A voucher specimen (HTSA7231) was deposited at the Herbarium of the Semi-Arid Tropic (HTSA) of the Brazilian Agricultural Research Corporation (EMBRAPA). The leaves were dried in room temperature for four days. The dried leaves $(100 \mathrm{~g})$ at room temperature was subjected to hydrodistillation for $3 \mathrm{~h}$ in a modified Clevenger-type apparatus. The oil yield was found to be $1.2 \mathrm{~mL}$. The oil was dried over anhydrous sodium sulfate. The essential oil obtained had a yellow color and characteristic odor. The oil was stored in a refrigerator until the analysis by GC-MS.

The compositional analysis the L. schaueriana essential oil was investigated in a semi quantitative way on a Shimadzu QP-2010 Gas Chromatograph interfaced to a mass spectrometer (GC-MS). The following conditions were used: DB-5MS column Agilent Technologies ( $30 \mathrm{~m} .0 .25 \mathrm{~mm} .0 .25 \mu \mathrm{m})$; helium $(99.999 \%)$ carrier gas at a constant flow of $1.1 \mathrm{~mL} / \mathrm{min} ; 1.0 \mu \mathrm{L}$ injection volume; injector split ratio of 1:10; injector temperature $250^{\circ} \mathrm{C}$; electron impact mode at $70 \mathrm{eV}$; ion-source temperature $280^{\circ} \mathrm{C}$ and transfer line temperature $260^{\circ} \mathrm{C}$. The oven temperature was programmed from $60^{\circ} \mathrm{C}$ to $240{ }^{\circ} \mathrm{C}$ at a temperature ramp of $3{ }^{\circ} \mathrm{C} / \mathrm{min}$.

A mixture of linear hydrocarbons $(\mathrm{C} 9 \mathrm{H} 20-\mathrm{C} 21 \mathrm{H} 40)$ was injected under the same experimental conditions that the samples and the identification of the constituents was performed by comparing the mass spectra obtained with those of the equipment database (Wiley 7 lib and NIST 08 lib), using the Kovats Index. The data were processed with help of the Shimadzu GC-MS Solution software.

The identification of the components was performed based on comparison of retention indices in literature [30]. For the retention index, the equation of van den Dool and Kratz [31] was used relative to a homologous series of n-alkanes $\left(\mathrm{nC}_{9}-\mathrm{nC}_{18}\right)$. Three libraries of the equipment WILEY8, NIST107, and NIST21 were used, which allows data comparison of the spectra with those contained in the libraries using an $80 \%$ similarity index.

\section{Conclusions}

The results presented in this first study for Lippia schaueriana are unpublished. The chemical composition of the essential oil showed the strong potential of this species for commercial use of the chemical, pharmaceutical, and fragrance industries.

This communication reports interesting information about the essential oil of this species and may be the starting point for future work on the biotechnological properties of a species not yet researched scientifically.

Author Contributions: A.V.V.d.S. was responsible for the plant collection, interpreted the results and drafted the manuscript. U.S.d.S., J.R.d.S.C., and B.D.R.B were responsible for the preparation of the material and extraction of the essential oil. K.M.C and T.H.S.R. were responsible for the chemical analysis of the essential oil. All authors read and approved the final manuscript.

Funding: The authors thank FACEPE for the financial support for this research.

Conflicts of Interest: The authors declare no conflict of interest. 


\section{References}

1. Atkins, S.V. The Families and Genera of Flowering Plants; Kadereit, J.W., Ed.; Springer: Berlin, Germany, 2004; pp. 449-468.

2. Salimena, F.R.G.; Kutschenco, D.C.; Monteiro, N.P.; Myssen, C.V. Red Book of Flora of Brazil; Martinelli, G., Moraes, M.A., Eds.; CNC Flora: Rio de Janeiro, Brazil, 2013; pp. 1010-1016.

3. The Vascular Plant Collection at the Botanische Staatssammlung München. Available online: https://www. gbif.org/occurrence/1099055877 (accessed on 22 May 2018).

4. Lippia schaueriana in Flora of Brazil 2020. Botanical Garden of Rio de Janeiro. Available online: http: / / www.floradobrasil.jbrj.gov.br/reflora/floradobrasil/FB21453 (accessed on 30 October 2017).

5. Lippia schaueriana in Flora Brasiliensis. Available online: http://florabrasiliensis.cria.org.br/search?taxon id748 (accessed on 27 October 2017).

6. Oliveira, J.A.; Bonvicino, C.R. Mammals of Brazil; Mammals of Brazil: Londrina, Brazil, 2006; Volume 31, pp. 231-276.

7. Cardoso, M.G.; Shan, A.Y.K.V.; Souza, L.A. Phytochemistry and Chemistry of Natural Products; UFLA: Lavras, Brazil, 2001; p. 67.

8. Simões, C.M.O.; Spitzer, V. Volatiles oils. In Pharmacognosy; Simões, C.M.O., Ed.; UFRGS: Porto Alegre, Brazil, 2004; pp. 387-4125. ISBN 85-7025-590-X.

9. Gobbo-Neto, L.; Lopes, N.P. Medicinal plants: Influence factors on the content of secondary metabolites. New Chem. 2007, 30, 374-381.

10. Cook, C.M.; Maloupa, E.; Kokkini, S.; Lanaras, T. Differences between the inflorescence, leaf and stem essential oils of wild Mentha pulegium plants from zakynthos, greece. J. Essent. Oil Res. 2007, 19, 239-243. [CrossRef]

11. Ikan, R. Select Topics in the Chemistry of Natural Products; World Scientific Publication: Jerusalem, Israel, 2008; p. 58.

12. Falcão, D.Q.; Menezes, F.S. Ethnopharmacological, pharmacological and chemical revision of the genus Hyptis. Rev. Bras. Farm. 2003, 84, 69-74.

13. Koliopoulos, G.; Pitarokili, D.; Kioulos, E.; Michaelakis, A.; Tzakou, O. Chemical composition and larvicidal evaluation of Mentha, Salvia, and Melissa essential oils against the West Nile virus mosquito Culex pipiens. Parasitol. Res. 2010, 107, 327-335. [CrossRef] [PubMed]

14. Vázquez, A.M.; Aimar, M.L.; Demmel, G.I.; Cabalen, M.E.; Decarlini, M.F.; Cantero, J.J.; Criado, S.G.; Ruiz, G.M. Identification of volatile compounds of Clinopodium odorum (Lamiaceae): A comparison between HS-SPME and classic hydrodistillation. Boletín Latinoamericano y del Caribe de Plantas Medicinales y Aromáticas 2014, 13, 285-296.

15. Dias, G.O.C.; Morel, A.F.; Ilha, V. Isolation and Identification of the Main Chemical Constituent of the Essential Oil of Menta rotundifolia (L.) Huds and Its Possible Applications. Anais 63 ; Reunião da SBPC: Goiânia, Brazil, 2011.

16. Lima, T.C.; Silva, T.K.; Silva, F.L.; Barbosa-Filho, J.M.; Marques, M.O.; Santos, R.L.; Cavalcanti, S.c.; Sousa, d.p. Larvicidal activity of Mentha $\times$ villosa Hudson essential oil, rotundifolone and derivatives. Chemosphere 2014, 104, 37-43. [CrossRef] [PubMed]

17. Teles, S.; Pereira, J.A.; Santos, C.h.B.; Menezes, R.V.; Malheiro, R.; Luchchese, A.M.; Franceli, S. Effect of geographical origin on the essential oil content and composition of fresh and dried Mentha $\times$ villosa Hudson leaves. Ind. Crop. Prod. 2013, 46, 1-7. [CrossRef]

18. Almeida, R.N.; Hiruma, C.A.; Barbosa-Filho, J.M. Analgesic effect of rotundifolone in rodents. Fitoterapia 1996, 67, 334-338.

19. Sousa, P.J.C.; Magalhães, P.J.C.; Lima, C.C.; Oliveira, V.S.; Leal-Cardoso, J.H. Effects of piperitenone oxide on the intestinal smooth muscle of guinea pig. Braz. J. Med. Biol. Res. 1997, 30, 787-791. [CrossRef] [PubMed]

20. Sousa, P.J.C.; Linard, C.F.B.M.; Azevedo-Batista, D.; Oliveira, A.C.; Coelho-de-Souza, A.N.; Leal-Cardoso, J.H. Antinociceptive effects of the essential oil of Mentha $\times$ villosa leaf and its major constituent piperitenone oxide in mice. Braz. J. Med. Biol. Res. 2009, 42, 655-659. [CrossRef] [PubMed]

21. Lorenzi, H.; Matos, F.J.A. Medicinal Plants of Brazil: Natives and Exotics, 2nd ed.; New Odessa: São Paulo, Brazil, 2008. 
22. Dorman, H.J.; Kosar, M.; Kahlos, K.; Holm, Y.; Hiltunen, R. Antioxidant properties and composition of aqueous extracts from mentha species, hybrids, varieties and cultivars. J. Agric. Food Chem. 2003, 51, 4563-4569. [CrossRef] [PubMed]

23. Tripathi, A.K.; Prajapati, V.; Ahmad, A.; Aggarwal, K.K.; Khanuja, S.P. Piperitenone oxide as toxic, repellent, and reproduction retardant toward malarial vector Anopheles stephensi (Diptera: Anophelinae). J. Med. Entomol. 2004, 41, 691-698. [CrossRef] [PubMed]

24. Agnaniet, H.; Makani, T.; Akagah, A.; Menut, C.; Bessière, J.M. Volatile constituents and antioxidant activity of essential oils from Lippia multiflora Mold. growing in Gabon. J. Flavour Fragr. 2005, 20, 34-38. [CrossRef]

25. Kounle, O.; Okogun, J.; Egemana, E.; Emojevwe, E.; Shok, M. Antimicrobial activity of various extracts and carvacrol from Lippia multiflora leaf extract. Phytomedicine 2003, 10, 59-61. [CrossRef] [PubMed]

26. Lemos, T.L.G.; MAatos, F.J.A.; Alencar, J.W. Antimicrobial activity of essential oils of Brazilian plants. Phytother. Res. 1990, 4, 82-84. [CrossRef]

27. Pascual, M.E.; Slowing, K.; Carretero, E.; Sánchez Mata, M.; Villar, A. Lippia: Traditional uses, chemistry and pharmacology: A review. J. Ethnopharmacol. 2001, 76, 201-214. [CrossRef]

28. Albuquerque, C.C.; Camara, T.R.; Mariano, R.L.R.; Willadino, L.; Júnior, C.M.; Ulisses, C. Antimicrobial Action of the Essential Oil of Lippia gracilis Schauer. Braz. Arch. Biol. Technol. 2006, 49, 527-535. [CrossRef]

29. Mendes, S.S.; Bomfim, R.R.; Jesus, H.C.R.; Alves, P.B.; Blank, A.F.; Estevam, C.S.; Antoniolli, A.R.; Thomazzi, S.M. Evaluation of the analgesic and anti-inflammatory effects of the essential oil of Lippia gracilis leaves. J. Ethnopharmacol. 2010, 129, 391-397. [CrossRef] [PubMed]

30. Adams, R.P. Identification of Essential Oil Components by Gas. Chromatography/Mass Spectroscopy, 4th ed.; Allured Publishing Corporation: Carol Stream, IL, USA, 1995.

31. Dool, H.V.; Kratz, P.D.J.A. Generalization of the retention index system including linear temperature programmed gas-liquid partition chromatography. J. Chromatogr. A 1963, 11, 463-471. [CrossRef]

Sample Availability: Samples of the essential oil from leaves of Lippia schaueriana are available from the authors.

(C) 2018 by the authors. Licensee MDPI, Basel, Switzerland. This article is an open access article distributed under the terms and conditions of the Creative Commons Attribution (CC BY) license (http://creativecommons.org/licenses/by/4.0/). 